\title{
På vej mod en målbevidst, målstyret kompetenceorienteret matematikundervisning
}

\author{
Rune Hansen, lektor, Læreruddannelsen UC Syd \\ \& Aarhus Universitet.ruha@ucsyd.dk
}

\begin{abstract}
Resumé
Artiklen har til formål at give indblik i potentialer og udfordringer ved at planlægge, gennemføre og evaluere en målstyret kompetenceorienteret matematikundervisning. Med afsæt i et igangværende forskningsprojekt vil en del af projektets analyser blive præsenteret som udgangspunkt for at kunne forholde sig til de hindringer af eksemplarisk karakter, som er identificeret i forbindelse med en længerevarende forsøgsundervisning i 5. og 6. klasse.

Nøgleord

Målstyring, matematikundervisning, kompetence, potentialer, hindringer, læreplan
\end{abstract}

Artikel inden for tema. Fagfællebedømt

\section{Et undervisningsbillede}

Det er midt på formiddagen. Eleverne i femte klasse sidder i bordgrupper og venter stille på, at matematiktimen går i gang. Matematiklæreren Tine sætter sig på en stol og spørger eleverne "Hvad tænker I, når vi bruger ordet mål? Når vi siger, at vi har et mål med noget. Hvad tænker I så på?"

Ved en bordgruppe rækker eleverne hurtigt hænderne op. Tine vælger Noah, der siger "At gå efter noget."

Tine svarer, mens hun organiserer tingene på sit bord. "Ja, at gå efter noget. Det er faktisk en god ting, ja. Hvad kunne det være for eksempel Noah?"

Noah begynder at sidde uroligt på sin stol, og efter et stykke tid siger han tøvende: "Æhhhh... det ved jeg snart ikke." Tine fokuserer på Noah og siger spørgende: "Nej." Det ansporer Noah til at svare: "Et mål i et maratonløb eller noget." 
Flere elever ved Noahs bordgruppe markerer med hænderne, mens Tine får Noah til at uddybe sit svar ved at sige: "Ja et maratonløb, der har man et mål. Og hvad er målet ved et maratonløb? Det er og..." Noah griber spørgsmålet og siger: "Det er og komme hele vejen rundt og nå til mål."

Tine anerkender Noahs forklaring og vender sig mod Emil. "Hvad siger Emil?"

"Mål det er sådan noget, der står ud på "sporteren"."

Mikkel udbryder lavmælt "for helvede" og Emil vender sig mod ham.

Tine siger: "Ja det er rigtigt", hvorefter hun henvender sig til Mikkel. "Hvad er målet for eksempel, når man siger, det er ude på sporteren? Hvad er mål Mikkel, hvis du spiller fodboldkamp, hoad er dit mål med en fodboldkamp?" Mikkel svarer: "Og score mål." Tine smiler og siger: "Ja det er rigtigt. Så der har du også et mål, som har noget med mål og gøre."

\section{Indledning}

Den ovenstående undervisningssekvens markerer de allerførste minutter fra den første klasserumsobservation i forbindelse med mit forskningsprojekt om målstyret kompetenceorienteret matematikundervisning. Sekvensen giver indblik i, at mål kan forstås på mange måder blandt elever i en femte klasse. Det er dog ikke kun blandt elever i femte klasse at forskellige målforståelser florerer, hvilket forhåbentlig vil blive tydeligt gennem artiklen. Umiddelbart virker det oplagt at beskæftige sig med genstandsfeltet på grund af dets aktualitet i forbindelse med folkeskolereformen, og mit forskningsprojekt har da også udviklet sig parallelt med andre danske forskningsbidrag (Carlsen, Tamborg, \& Hansen, 2016; Skott \& Kaas, 2015). Som en del af demonstrationsskoleprojektet Digitalt Understøttede Læringsmål (Misfeldt, 2016) har Carlsen et al. (2016) undersøgt tyve dansk- og matematiklæreres målforståelser ved hjælp af interview og undervisningsobservationer. Undersøgelsen giver indblik i, at lærernes målforståelse er udspændt mellem to målmetaforer om retning og styring, der knytter sig til forskellige undervisningsmæssige situationer og lærerens faglige beredskab. Eksempelvis beskrives to modsatrettede forhold i forbindelse med styringsmetaforen, hvor mål angiver en ufravigelig destination for undervisningen. "Det opleves af lærerne på den ene side som en spændetrøje - på den anden side opleves det af den fagligt usikre lærer som et nyttigt og ligefrem nødvendigt stillads" (Carlsen et al., 2016, s. 27). Ved at fokusere på læreres planlægningspraksis i et udviklings- og forskningsprojekt med seks dansk og matema- 
Rune Hansen: På vej mod en målbevidst, målstyret kompetenceorienteret ...

tiklærere har Skott og Kaas observeret, at lærerne ikke har "et påtrængende behov for at konkretisere eller selv formulere mål" (Skott \& Kaas, 2015, s. 19). I forbindelse med planlægning af matematikundervisning anbefaler Skott og Kaas en orientering mod mål i form af faglige fokuspunkter. Et norsk forskningsprojekt "Sammenhæng mellem undervisning og læring" har i forbindelse med kundskabsløftet LK06 undersøgt implementeringen af nye kompetenceorienterede målbeskrivelser i undervisningen (Hodgson, Rønning, Skogvold, \& Tomlinson, 2010; Hodgson, Rønning, \& Tomlinson, 2012). Her fandt forskerne indledningsvis en stor variation i brugen af mål, hvor en del lærere eksempelvis ikke havde omformet de officielle målbeskrivelser i udarbejdelsen af deres undervisningsplaner (Hodgson et al., 2010). I slutrapporten er et tydeligt fund, at "lærerne ser ud til at have godtaget måldrevet læring som en eksplicit tilnærmelse til undervisningen" (Hodgson et al., 2012, s. 14) (min oversættelse). Hodgson et al. (2012) stiller sig dog spørgende til, hvordan den intense målfokusering påvirker elevers læring og relaterer spørgsmålet til en negativ fragmentering af læringsarbejdet.

Karakteristisk for de forskellige bidrag er, at de kan kvalificere den uddannelsespolitiske og pædagogisk-didaktiske diskurs i forbindelse med udvikling af målstyret kompetenceorienteret matematikundervisning. Det er en lignende motivation, der ligger bag mit forskningsprojekt, hvor jeg er optaget af at undersøge, hoad der kan karakterisere målstyret kompetenceorienteret matematikundervisning. Artiklen har som formål at gøre læseren opmærksom på hindringer, der kan opstå, når matematiklærere skal planlægge, gennemføre og evaluere en målstyret kompetenceorienteret matematikundervisning. Analyserne i artiklen indbyder forhåbentlig læseren til refleksion over den tænkning og de styringsmekanismer, der er indført med skolereformen. Indledningsvis præsenterer artiklen den metodologiske ramme for mit projekt og dets forskningsprocesser. Dernæst beskrives forskellige perspektiver på læreplaner, der fører til en indkredsning af begrebet "kompetenceorienteret matematikundervisning". Her identificeres nogle ganske særlige udfordringer for matematikfaget, hvilket leder frem mod en afdækning af forskellige typer af læringsmål samt elevernes orientering mod dem. Med afsæt i disse analyser diskuteres, hvordan matematiklærere kan udvikle en bevidsthed om anvendelsen af forskellige typer af læringsmål i planlægning, gennemførelse og evaluering af en målstyret matematikundervisning. De teoretiske analyser efterfølges af en beskrivelse af en konkret forsøgsundervisning. Det skaber datagrundlaget for det analytiske afsnit, 
der identificerer hindringer for en målstyret kompetenceorienteret matematikundervisning. Artiklen afrundes ved at diskutere disse hindringer i relation til andre forskningsbidrag.

\section{Didaktisk modellering, en forskningsbaseret tilgang til udvikling af undervisning}

Projektet tænkes inden for rammerne af en didaktisk modelleringsproces (Blomhøj \& Jensen, 2007; Højgaard \& Hansen, 2016), hvor mit udgangspunkt er en systematisk, forskningsbaseret udvikling af målstyret kompetenceorienteret matematikundervisning. Inspireret af den matematiske modelleringsproces opereres med forskellige faser, hvor jeg med afsæt i et teoretisk plan nærmer mig en konkret praksis ved at foretage en række reflekterede valg. Som et støttende stillads for forskningsprocessen anvendes fortløbende forskningsspørgsmål til at bringe fremdrift i projektet (optræder med kursiv i artiklen). Gennem mit projekt forsøger jeg at stille skarpt på aspekter, der fremmer og udfordrer en målstyret kompetenceorienteret matematikundervisning. Projektet indledes ved at etablere forskellige teoretiske afgrænsninger af genstandsfeltet med afsæt i spørgsmålet:

\section{Hvilke potentialer kan jeg på baggrund af fagdidaktiske analyser argumentere for, at der er ved at arbejde med målstyrede logik- ker i grundskolens matematikundervisning?}

Ved at benytte begrebet potentiale søger jeg at accentuere mulige, men endnu ikke realiserede, handlinger. Disse handlinger relaterer sig til de målstyringspræmisser og logikker for undervisning, der er beskrevet i folkeskoleloven og Forenklede Fælles Mål for matematik. Begrundelsen for fagdidaktiske analyser baserer sig på min forståelse af fagdidaktik som en videnskabelig praksis, der søger at identificere, karakterisere og forstå fænomener og processer, der har indflydelse på og indgår i både en reel og en potentiel undervisning i matematikfaget og læring af matematik (Niss, 2015).

Det empiriske bidrag baserer sig på en forsøgsundervisning med én lærer og én klasse i grundskolen i en toårig periode. Det bevidste fokus på én klasse på mellemtrinnet gennem en længerevarende tidsperiode giver mulighed for et langvarigt feltarbejde med deltagende observation, hvor de komplekse undervisnings- og læreprocesser kan følges over tid. Inspireret af etnografiske tilgange (Borgnakke, 2013) giver det mig mulighed for at etablere andre 
Rune Hansen: På vej mod en målbevidst, målstyret kompetenceorienteret ...

perspektiver på genstandsfeltet end eksempelvis Carlsen et al. (2016) og Skott og Kaas (2015). Med afsæt i Flyvbjerg (2010) vil jeg argumentere for, at forsøgsundervisningen udgør en atypisk/ekstrem case, da mit samarbejde med læreren skaber et usædvanligt udgangspunkt for planlægningen af undervisningen. Her har jeg eksempelvis i planlægningsarbejdet været garant for, at læreren kontinuerligt har forholdt sig didaktisk reflekterende til officielle målbeskrivelser samt arbejdet med at udvikle en bevidsthed om brug af mål i undervisningen. Det er indlysende, at de identificerede hindringer i projektet er partikulære og kontekstafhængige fremfor universelle, men tilgangen har muliggjort en omfattende undersøgelse, hvor mine data (fx klasserumsobservation, interview, planlægningsskabeloner, lærerens præsentationer, elevprodukter) frembringer en detaljeret forståelse af hindringer ved en målstyret kompetenceorienteret matematikundervisning. I mine beskrivelser anvendes en analytisk generalisering, hvor mit fokus på hindringer skaber nogle resultater, der kan være vejledende for, hvad der kan ske i en anden situation (Brinkmann \& Kvale, 2008; Roald \& Køppe, 2008). Det virker i min optik rimeligt at antage, at mine resultater rummer en forsker- og læsergeneralisering, hvor en del matematiklærere nok vil opleve samme type af hindringer i forbindelse med at udvikle en målstyret kompetenceorienteret matematikundervisning.

\section{Formelle rammer for læreres målarbejde i matematik}

For at lave en afgrænsning er det relevant at forholde sig til et karakteristisk træk ved matematikundervisning i den danske grundskole. Flere forskningsprojekter har givet indblik $i$, at matematikfaget $i$ folkeskolen ofte er et opgave- og aktivitetsstyret fag, hvor læremidlet har stor indvirkning på undervisningens indhold. Eksempelvis beskriver flere danske undersøgelser lærebogens dominerende rolle i matematikundervisningen (Danmarks Evalueringsinstitut, 2012; Mogensen, 2011; Skott \& Kaas, 2015). Denne tendens genfindes i internationale undersøgelser (Remillard, 2005). Når læreren benytter sig af en sådan tilgang til undervisning i et fag, kan lærerens forståelse af faget hurtigt udvikle sig til at blive en statisk størrelse, der ikke påvirkes af nye matematikdidaktiske elementer. Samtidig muliggør det en praksis, hvor matematiklæreren ikke behøver at reflektere over sammenhængen mellem officielle målbeskrivelser for matematikfaget og tilrettelæggelse af egen undervisning (Blomhøj \& Højgaard, 2011). I forbindelse med matematiklæreres planlægningspraksis beskriver Skott og Kaas (2015), dels hvordan matematiklærerne ikke skelner mellem mål fra henholdsvis officielle beskri- 
velser og lærebogsmaterialet, og dels hvordan de ikke fandt nogen af målene anvendelige. Derfor vil afsnittet beskrive en række elementer, der er med til at etablere de formelle rammer for læreres målarbejde i matematik.

Ofte anvendes begrebet læreplan til at beskrive, hvad der skal læres i et fag. En læreplan er dermed en bestemmelse af formål, mål og indhold for et fag. Porter og Smithson (2001) skelner mellem fire typer af læreplaner': den intenderede, den gennemførte, den evaluerede og den lærte læreplan. Den intenderede læreplan er de officielle beskrivelser af et fag (Forenklede Fælles Mål). Den gennemførte læreplan relaterer sig til, hvad der rent faktisk foregår i undervisningen. Hvad er det for et matematisk indhold, eleverne møder i undervisningen? Den lærte læreplan refererer til elevers læringsudbytte af undervisningen i matematik, der naturligvis kun kan identificeres i et mere begrænset omfang. Den evaluerede læreplan henviser til, hvordan man fra politisk side vælger at evaluere elevers læringsudbytte (Porter \& Smithson, 2001). I det efterfølgende vil den analytiske skelnen mellem den intenderede læreplan og den evaluerede læreplan være med til at skabe opmærksomhedsfelter, der kan have afgørende indflydelse på den gennemførte og den lærte læreplan.

Forenklede Fælles Mål for matematik beskriver intentionerne med matematikundervisning i Danmark. Det er et politisk styringsredskab, der er fremstillet som en form for kompromistekst mellem forskellige tænkemåder (Lindhardt, 2016; Niss, 2016). Udgangspunktet for de aktuelle fags læreplaner i grundskolen har været kvalifikationsrammen for livslang læring, der anvender kategorierne viden, færdigheder og kompetencer (Undervisningsministeriet, 2010). I forbindelse med udarbejdelsen af Forenklede Fælles Mål i matematik har den ministerielt udpegede gruppe af fagdidaktikere stået over for den udfordring, at den kompetencebaserede systematik fra projektet Kompetence og matematiklæring (Niss \& Jensen, 2002) allerede var blevet integreret med Fælles Mål 2009 (Undervisningsministeriet, 2009). Ifølge Niss og Jensen (2002) besidder en elev matematisk kompetence, når vedkommende har en indsigtsfuld parathed til at handle hensigtsmæssigt i situationer, som rummer en bestemt slags matematisk udfordring. I masteren beskrives, at "Eleverne viser kompetence i konkrete situationer ved at bruge viden og færdigheder til at løse opgaver og reflektere over opgaveløsningen" ("Master for forenkling af Fælles Mål," 2013, s. 4). Her bliver potentialet til at handle

1 Jeg har valgt at oversætte begrebet "curriculum" til læreplan, da Porter og Smithsons beskrivelser relaterer sig til bestemmelse af formål, mål og indhold for et fag. 
Rune Hansen: På vej mod en målbevidst, målstyret kompetenceorienteret ...

i ukendte og uforudsigelige matematiske situationer reduceret til at kunne bruge viden og færdigheder til at løse matematiske opgaver.

Læreplansgruppen i matematik har stået overfor en stor udfordring i forbindelse med at sammenkoble kompetencetænkningen fra KOM-projektet med kompetencetænkningen fra masterbeskrivelsen. I det følgende skitseres nogle af de modsatrettede elementer, læreplansgruppen har været nødt til at forholde sig til (Lindhardt, 2016). KOM-projektet identificerer otte matematiske kompetencer, der samlet udspænder begrebet matematisk kompetence. Det betones, at matematiske kompetencer både udvikles og udøves i omgangen med forskellige faglige stofområder. Rapporten undlader bevidst at fremkomme med en særlig udmøntning af hvilket fagligt stof, der skal relateres til en specifik kompetence. Det fremhæves, at det "er en sag, som kræver selvstændig stillingtagen" (Niss \& Jensen, 2002, s. 82). I forbindelse med udvikling af kompetencetænkningen for matematikfaget beskriver Mogens Niss, at "Den vigtigste fare består i at forlade det sammenfattende og overordnede beskrivelsesniveau, for i stedet at gå i detaljer med udparcellering og selvstændiggørelse - atomisering - af kompetenceelementer" (Niss, 2001). Her betones det problematiske ved at fremkomme med enkle og præcise målbeskrivelser, som masteren lægger op til.

I udviklingen af Forenklede Fælles Mål er læreplansgruppen gået på kompromis med ensartethed på tværs af fagene ved at lade de fire kompetenceområder bestå af: matematiske kompetencer, tal og algebra, geometri og måling, statistik og sandsynlighed. Kompetencemålene til kompetenceområdet matematiske kompetencer giver indblik i, hvordan læseplansgruppen har efterstræbt at få kompetenceforståelsen fra KOM-projektet ind i de nye målbeskrivelser.

\begin{tabular}{l|l|l|l} 
& Efter 3. klassetrin & Efter 6. klassetrin & Efter 9. klassetrin \\
\hline Kompetencemål & Eleven kan handle & Eleven kan handle & Eleven kan handle \\
& hensigtsmæs- & med overblik i & med dømme- \\
& sigt i situationer & sammensatte & kraft i komplekse \\
& med matematik & situationer med & situationer med \\
& & matematik & matematik
\end{tabular}

Figur 1 Kompetencemål for "matematiske kompetencer"

Desuden er inspirationen fra KOM-projektets matrixmodel tydelig, og der er en klar intention om, at de matematiske kompetencer skal relateres til de matematiske stofområder. 
Model for planlægningen af undervisningsforløb i matematik.

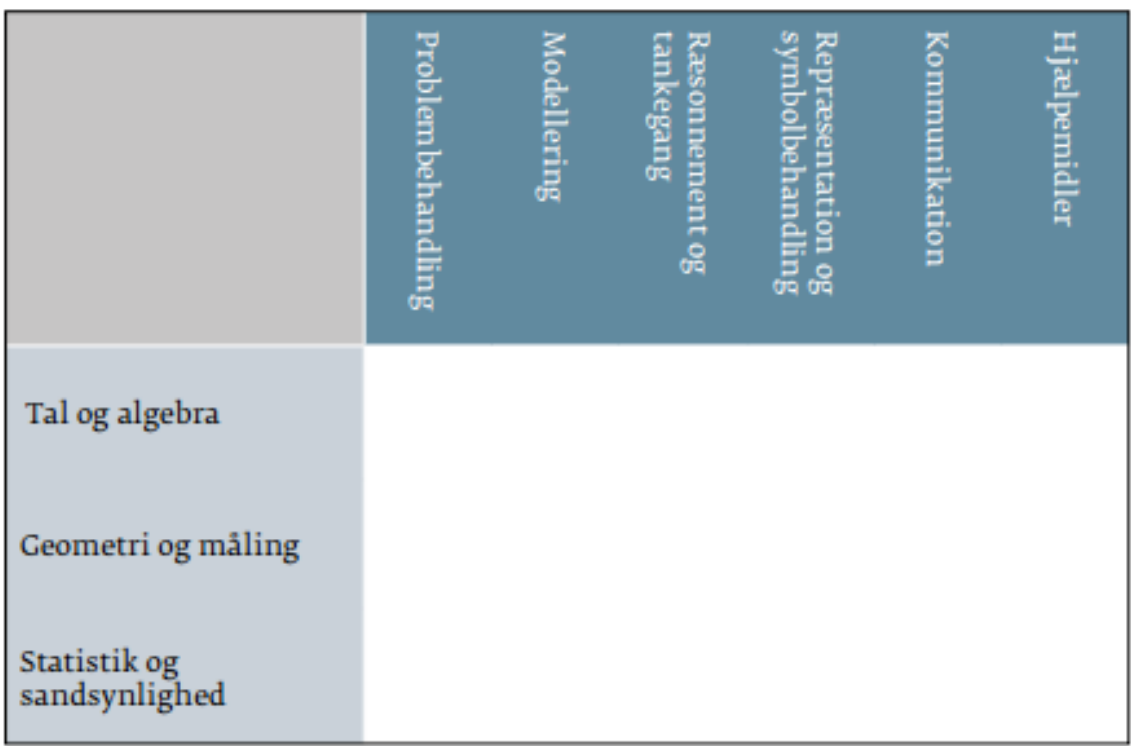

Figur 2 Matrixmodel for kobling af kompetencer og stofområder

Kompromisteksten skaber dog et meget diffust kompetencebegreb i Forenklede Fælles Mål for matematik (Lindhardt, 2016; Niss, 2016). Der opereres med fire kompetenceområder, hvoraf det ene er benævnt matematiske kompetencer, mens de tre andre områder er klassiske matematiske stofområder. Det bevirker, at matematiklærere selv skal forsøge at skabe en syntese for, hvad kompetenceorienteret matematikundervisning egentlig indebærer for eleverne, da de oprindelige kompetencer er omskrevet til færdigheds- og vidensmål.

Man kan hævde, at Forenklede Fælles Mål (FFM) for matematik tager matematiklærerens faglighed alvorligt og åbner for en nytænkning af en række didaktiske valg i forbindelse med at planlægge, gennemføre og evaluere matematikundervisningen. For at intentionerne med de forenklede mål kan blive opfyldt, er det centralt, at matematiklærere eksperimenterer med at få de to dimensioner til at interagere på en konstruktiv og naturlig måde. Niss (2016) argumenterer for, at mål potentielt har mulighed for at tydeliggøre matematiklærerens faglige og didaktiske formål med et undervisningsforløb. Mål kan dermed relateres til en tydeliggørelse af den didaktiske intentionalitet, som matematiklæreren går ind i klasserummet med. Jeg vil derfor argumentere for, at mål bør udgøre en af de bærende konstruktioner i matematiklæreres planlægningspraksis.

Niss betoner endvidere, at "anvendelsen af evalueringsmidler, som ikke matcher kernen i det, der skal evalueres, ender med at kompromittere denne 
Rune Hansen: På vej mod en målbevidst, målstyret kompetenceorienteret ...

kerne" (Niss, 2016, s. 73). Når jeg analyserer den evaluerede læreplan for begynder- og mellemtrinnet i grundskolen, er der indikationer på noget sådant. I den evaluerede læreplan udgør standardiserede test en betydningsfuld rolle, da elevers præstationer i matematik sammenholdes med politiske krav om forbedringer i skolen. Det fremgår tydeligt af aftaleteksten om et fagligt løft af folkeskolen: "Målene for elevernes faglige udvikling vil blive opgjort på baggrund af elevernes resultater i de nationale test" (Aftale om et fagligt løft af folkeskolen, 2013, s. 23). Det er dog kun stofområderne tal og algebra, geometri og måling samt statistik og sandsynlighed, der indgår i testen. Ved at sammenholde den evaluerede læreplan med den intenderede læreplan er det iøjnefaldende, at den evaluerede læreplan ikke måler elevernes matematiske kompetenceudvikling. Der er altså en diskrepans mellem læreplansgruppens fastholdelse af betydningen af de matematiske kompetencer fra KOM-projektet, og hvad der værdsættes i evalueringen. Fra officiel side bliver den evaluerede læreplan udtryk for et simplificeret syn på matematikfaget.

Implementering af kompetencetænkningen fra den intenderede læreplan $i$ en konkret undervisning er et meget ambitiøst projekt. Det stiller store krav til matematiklærerens faglighed, når vedkommende skal operationalisere tænkningen i en konkret undervisningssituation. En svensk undersøgelse af kompetenceorienteret matematikundervisning viser, at der er langt fra intentionerne i læreplanen om en kompetenceorienteret undervisning til den konkrete udmøntning i praksis. De svenske matematiklærere har generelt svært ved at forholde sig nuanceret til kompetencemålene (Boesen et al., 2014), samtidig har en forholdsvis stor del af lærerne kun en begrænset forståelse for de matematiske kompetencer (Bergqvist et al., 2010). Noget tilsvarende er observeret i Danmark (Danmarks Evalueringsinstitut, 2006), hvilket Bent Lindhardt fra læreplansgruppen også giver udtryk for: "Når jeg kommer rundt i sådanne sammenhænge oplever jeg imidlertid ofte en noget stor afstand fra "at have hørt om" og så en indsigt som gør det muligt at operere med kompetencerne i den daglige undervisning" (Lindhardt, 2016). Det kommer også til udtryk i undersøgelserne fra Skott og Kaas (2015) samt Hodgson et al. (2010), hvor nationale mål ikke omformes, men bare skrives ind i undervisningsplanen. Der er indikationer på, at det er vanskeligt at formulere mål for kompetencerne.

Den analytiske skelnen mellem de forskellige læreplaner tydeliggør, at matematiklæreres eventuelle manglende forståelse for de matematiske kompetencer og et stort uddannelsespolitisk fokus på måling af elevers læringsudbytte kan skabe en situation, hvor flere matematiklærere orienterer sig mere mod 
den evaluerede læreplan end den intenderede læreplan. For mange læreres vedkommende kommer den gennemførte undervisning altså til at bevæge sig i et krydsfelt mellem tydeligt målbare færdighedsmål for de matematiske stofområder og mere brede kompetencemål, der udfordrer elevers matematiske handleberedskab.

\section{Teoretiske indfaldsvinkler til begrebet læringsmål}

For at forstå begrebet læringsmål har jeg valgt at fokusere på den amerikanske læreplansudvikling, hvor læringsmål har været udførligt debatteret. Jeg vil i denne artikel udelukkende skitsere nogle elementer, som kan genfindes i den nuværende danske diskurs, om brugen af læringsmål.

Fra begyndelse af det 20. århundrede skabes en mål-middel-tænkning inden for læreplansudviklingen i USA. Ralph Tyler (1977) og Robert Mager (1962) beskriver blandt andet, at overordnede indholdsområder skal transformeres gennem en proces, hvor mere almene målbeskrivelser omformuleres til klare og præcise termer for elevadfærd. Samtidig skal læringsmål være styrende for valg af midler. Eksempelvis siger Mager, at fagene skal beskrives i specifikke og detaljerede målbeskrivelser, som eleverne tilgår i forskellig rækkefølge (Mager, 1962; 1968). Skolereformens introduktion af læringsmålstyret undervisning har tydelige markeringer af den tænkning.

\section{"Målene skal formuleres, så de er tydelige for eleverne og styrende for læringsaktiviteterne. Det skal være tydeligt for eleverne, hvad de skal kunne vise, de kan undervejs i forløbet, og når forløbet er afsluttet, hvis målene skal være nået" (Undervisningsministeriet, 2014 , s. 4).}

Den danske udlægning af læringsmålstyret undervisning er blevet udsat for en del kritik i den aktuelle uddannelsespolitiske diskurs². Men allerede i samtiden kritiseredes den af eksempelvis Elliot Eisner (1967), som betonede, at mål-middeltrnkningen havde en tendens til at overvurdere, hvad man kunne formulere som observerbare adfærdsmål. Han påpegede, at viden ikke burde begrænses til, hvad man kunne eksplicitere i målbeskrivelser. Eisner er tilhænger af åbne, fleksible og retningsangivende målangivelser, hvor lærere får mulighed for at lade dem indgå på en kreativ og dynamisk

Se fx folkeskolen.dk 
Rune Hansen: På vej mod en målbevidst, målstyret kompetenceorienteret ...

måde i deres organisering af undervisningen (Eisner, 1967). Derfor skelner Eisner også mellem instruktive og ekspressive mål, hvor instruktive mål entydigt beskriver en specifik adfærd, som en elev skal erhverve sig efter at have arbejdet med læringsaktiviteter. Ekspressive mål beskriver et uddannelsesmæssigt møde, hvor lærer og elever inviteres til at undersøge situationer, som de finder interessante (Eisner, 1969).

Som en del af min afdækning vælger jeg også at undersøge, hvad der eksisterer af empiriske forskningsresultater i forbindelse med brug af mål i matematikundervisningen. Gennem et systematisk review (Hansen, 2015) opnår jeg indsigt i en række forskningsbidrag om elevers intentioner og/eller begrundelser for at nå et mål. Her er identificeret to målkategorier: præstationsmål og mestringsmål. Når elever er orienteret mod præstationsmål, har de en større tendens til at anvende overfladiske læringsstrategier (Meece, Anderman, \& Anderman, 2006) og er optaget af kortsigtede mål som at svare rigtig på spørgsmål og klare sig godt i test (Sullivan, Tobias, \& McDonough, 2006). Endvidere foretrækker de individuelt opgavearbejde og er generelt mindre villige til at arbejde sammen med klassekammerater. Det gælder især, når kammeraten anses for værende på et andet fagligt niveau (Midgley, Kaplan, \& Middleton, 2001). Elever med en præstationsorienteret tilgang har endvidere en præference for lette opgaver. De er optaget af at blive hurtigt færdigt med opgaverne i stedet for at reflektere over dem. De giver let op, undgår at søge hjælp og undlader at rette fejl og fejltagelser (Turner, Thorpe, \& Meyer, 1998). Elever orienteret mod mestringsmål er mere vedholdende i forbindelse med at løse matematiske opgaver, samtidig har elever med en sådan tilgang også en større tendens til at anvende kognitive og metakognitive strategier (Wolters, 2004). Elever med en mestringsorienteret tilgang giver ikke op over for udfordrende opgaver. De er involveret i opgaveløsningen og søger opgaverelaterede informationer såvel som at få bekræftet, om de er på rette vej i løsningsprocessen (Newman \& Schwager, 1995). Mit review giver indblik $i$, at elevers målorientering ikke er statiske størrelser, men udvikler sig over tid. Endvidere har konteksten indflydelse på elevers målorienteringer, hvor den samme elev i forskellige kontekster kan orientere sig mod henholdsvis præstations- og mestringsmål (Hansen, 2015).

Gennem afklaringen har jeg fået etableret forskellige perspektiver på mål samt dannet analytiske kategorier til at fortolke og forstå lærere og elevers handlinger i forbindelse med en målstyret undervisning. De foregå- 
ende analyser tegner et komplekst billede af mål, som matematiklærere bør være bevidste om i forbindelse med at udvikle en målstyret kompetenceorienteret matematikundervisning. Hvor Hodgson et al. (2012) fremhæver måldrevet læring som en tilnærmelse til undervisning, er Niss (2016) optaget af en målstyret undervisning. Måldrevet læring knytter an til specifikke færdighedsmål, som efterfølgende kan vurderes som værende opnået (præstationsmål). Derimod relaterer målstyret undervisning sig til mere åbne, fleksible og retningsangivende målangivelser (Eisner, 1969), hvor læreren i overensstemmelse med folkeskolelovens §18, stk. 4 samarbejder med elever om "fastlæggelse af de mål, der søges opfyldt." I forbindelse med at udvikle en målstyret undervisning beskriver et læringsmål, hvad eleven skal kunne i forhold til et fagligt indhold. Men læringsmålet behøver ikke at have en entydig præstationsorientering i forhold til et fagligt indhold, derimod kan læringsmålet være med til at skabe dialog i klasserummet om, hvad eleverne skal lære for at udvikle autonomi til at handle med deres "matematik". Herved vil den målstyrede undervisning rette sig mere mod den intenderede læreplan end den evaluerede læreplan.

\section{Hypotetisk læringskurs - et redskab til matematiklærerens styring af undervisningen}

De foregående abstrakte analyser skaber en række opmærksomhedsfelter i forbindelse med at udvikle en målstyret kompetenceorienteret matematikundervisning. I mit projekt forpligter jeg mig på at oversætte de abstrakte analyser til en rammesætning af en konkret undervisningspraksis med afsæt i spørgsmålet

\section{Hvilke planlægnings- og tilrettelæggelsesmæssige karakteri- stika, i forhold til måden en målstyret tilgang kan inddrages på i grundskolens matematikundervisning, kan jeg med afsæt i den teoretiske analyse udpege for værende centrale, hvis målet er at udvikle elevernes matematiske kompetencer?}

I denne del af mit projekt har jeg udviklet forskellige didaktiske positioner, der kan bidrage til at svare på ovenstående spørgsmål. Det er ikke muligt at udfolde alle positioner i denne artikel, derfor vil der blive fokuseret på den position, der relaterer sig til lærerens arbejde med planlægning af undervisningen: 
Rune Hansen: På vej mod en målbevidst, målstyret kompetenceorienteret ...

\section{Undervisningen skal karakteriseres ved, at der udarbejdes en læringskurs for de enkelte forløb, hvor en hypotetisk sammen- hæng mellem læringsmål, aktiviteter, læremidler og stillad- serende elementer udgør pejlemærker for matematiklæreren i forhold til at styre mod målet.}

I forbindelse med intentionen om at oversætte mine abstrakte analyser til en konkret praksis er jeg i første omgang udfordret af målstyringsbegrebet. Inspireret af diskussionerne fra den amerikanske læreplanstænkning finder jeg det centralt, at læringsmål skal være med til at rammesætte og orientere læreres tænkning om deres undervisning. Lærere skal udvikle en form for didaktisk målbevidst målstyring, hvor de er bevidste om forskellige typer af læringsmål, samt hvordan de er med til at skabe undervisnings- og læringsmæssige pejlinger for eleverne. Som tidligere beskrevet er en stor del af matematikundervisningen orienteret mod opgaver og aktiviteter. Derfor er der inden for matematikundervisningen også et uforløst potentiale $\mathrm{i}$ at arbejde systematisk med forbindelse mellem meningsbærende mål og konkret faglig praksis (Højgaard, 2013), hvor den aktivistiske tilgang i matematikundervisningen afløses af et større fokus på elevers læring.

I den forbindelse inspireres jeg af Martin Simon (1995), der introducerer begrebet "learning trajectory". I dansk sammenhæng er termer som læringsbaner, læringsstier og læringsveje blevet anvendt $\mathrm{i}$ indkredsningen af "trajectory"-begrebet (Progression i de naturvidenskabelige fag, 2014). Jeg har dog valgt at oversætte begrebet til læringskurs i et forsøg på at imødegå en ide om, at matematisk læring kan beskrives på en forudsigelig, sekventiel måde, der metaforisk relaterer sig til en vej (Empson, 2011). Den hypotetiske læringskurs beskriver et refleksivt forhold mellem læringsmål, læringsaktiviteter og overvejelser vedrørende de tankegange og læreprocesser, som eleverne måske vil engagere sig i (Simon, 1995). Det eneste, læreren kan være sikker på i en undervisningssituation, er, at de forskellige aktiviteter aldrig vil fungere på lige præcis den måde, læreren har forestillet sig. Derfor skal planer også revideres, når læreren får mere indsigt i elevernes tænkning gennem interaktionen i klasserummet. Den hypotetiske læringskurs dannes af tre komponenter:

- Læringsmål, der definerer retningen (Simon, 1995).

- Læringsaktiviteter (Simon \& Tzur, 2004). 
- Den hypotetiske læreproces. Antagelse omkring, hvordan elevers tænkning og forståelser vil udvikle sig i undervisningssituationen (Simon, 2006).

Lærerens opgave bliver at simplificere en kompleks undervisningskontekst ved at foretage nogle valg, vel vidende at valgene måske ikke virker efter hensigten i den konkrete undervisningssituation. Simon introducerer en didaktisk model for sin tænkning, som jeg har modificeret en lille smule i figur 3.

Modellen er en forenkling af en række komplekse sammenhænge, men jeg ser en styrke i at anvende en model, som kan "holdes i hovedet" af læreren i forbindelse med planlægning og undervisning. Ved at fokusere på en hypotetisk sammenhæng mellem læringsmål, aktiviteter og elevers læreproces etableres en argumentationskæde fra det overordnede fagformål over de specifikke fagmål til den konkrete undervisningssituation. I min optik er der netop her tale om en didaktisk målbevidst målstyring, hvor læreren er interesseret $\mathrm{i}$ at finde ud af, hvilke mål elevers læringskurs retter sig mod ("rektanglet" ved pilens hoved viser elevernes indflydelse på kursen). "Mål" ved pilens spids fremhæver, at når matematiklærerens opstillede læringsmål møder eleverne i undervisningen, kan der foregå en dynamisk udvikling af læringsmålene. Det er et forsøg på at inkorporere fordringen fra folkeskoleloven om, at eleverne skal indgå i dialog med læreren om at etablere og fastlægge mål.

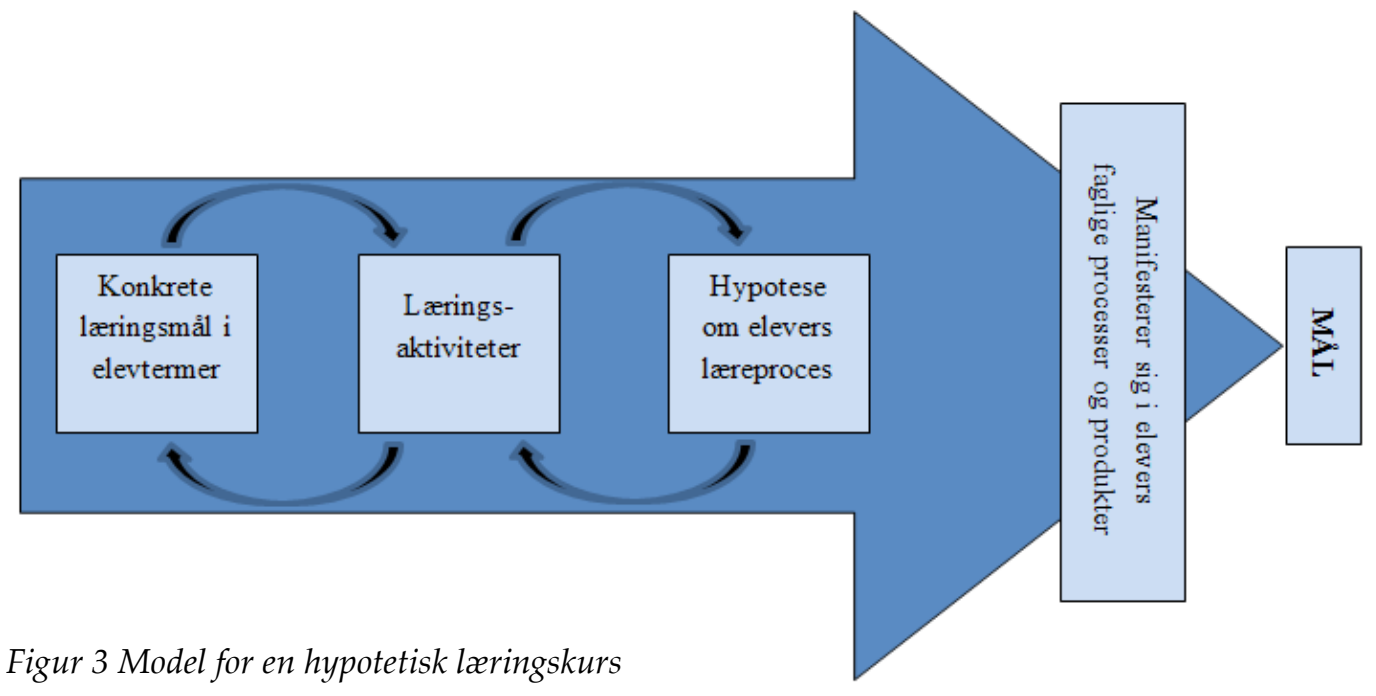


Rune Hansen: På vej mod en målbevidst, målstyret kompetenceorienteret ...

I en kompetenceorienteret matematikundervisning vil vi have elever til at udvikle en form for autonomi, så de kan handle hensigtsmæssigt i matematikholdige situationer. Læringskursen fremhæver betydningen af at have mål. Jo bedre matematiklæreren kender eleverne, det matematiske indhold og de didaktiske præmisser, desto lettere bliver det at sætte en relevant kurs for elevers rejse mod målet.

Metaforisk relaterer Simon (1995) ovenstående til en verdensomsejling. Inspireret af den indledende undervisningssekvens om at nå i mål i et maratonløb har jeg valgt at benytte metaforen orienteringsløb. Ved et orienteringsløb planlægger læreren en rute, der kan føre eleverne frem mod målet. Læreren indsætter en række poster (opgaver), eleverne skal omkring. Det kræver indsigt i en række faktorer at kunne planlægge ruten. Når eleverne begynder orienteringsløbet, vil deres ruter mod målet være meget forskellige. Hvis man tænker på et orienteringsløb i en skov, vil eksempelvis fysiske forhindringer som væltede træer eller sumpede områder føre til omveje. Ved at lade poster være lærerudpegede pejlemærker, hvor læreren på forhånd har gjort sig overvejelser omkring postens betydning $\mathrm{i}$ forhold til det centrale læringsmål, kan vedkommende vurdere om eleverne er på rette kurs, eller om de bevæger sig i en anden retning end mod det oprindelige læringsmål. Samtidig vil læreren kunne etablere differentierede benspænd ved at vurdere, om eleverne skal omkring forskellige poster. Det vil sige, at orienteringsløbet kontinuerligt ændres som konsekvens af de betingelser, der opstår. Elevernes omveje manifesterer sig fagligt, socialt og emotionelt, hvilket læreren skal kunne reagere på ved at tilføje nye poster, fjerne eksisterende poster og lade eleverne få mulighed for at samle kræfter (bruge mere tid) ved en post. Mens læreren har planlagt en hypotetisk læringskurs, vil elevernes læringskurs afspejle deres orientering mod forskellige mål i deres læreproces. Derfor er det også vigtigt, at eleverne bliver bevidste om de forskellige posters betydning for at nå målet.

Med den hypotetiske læringskurs har jeg fundet en didaktisk model, hvor målstyring relaterer sig til lærerens didaktiske intentionalitet, samtidig med at modellen baserer sig på en præmis om, at enhver undervisningssituation er en form for eksperiment, hvor alle aktører har indflydelse på eksperimentet. Det virker derfor oplagt at lade de teoretiske konstruktioner møde en konkret undervisningspraksis. 


\section{Forsøgsundervisning}

Denne del af forskningsprocessen styres af følgende forskningsspørgsmål:

\section{Hvad er karakteren af de forhindringer, der i en bestemt kontekst opstår, når matematiklærere forsøger at realisere en målstyret kompetenceorienteret matematikundervisning med afsæt i de udpegede centrale planlægnings- og tilrettelæggelsesmæssige karakteristika?}

Som beskrevet fokuseres på én lærer og én klasse i grundskolen i forbindelse med forsøgsundervisning $\mathrm{i}$ en toårig periode. Lige inden sommerferien $\mathrm{i}$ 2014 etableres kontakten med en interesseret lærer (Tine Rohden Mikkelsen) ved Stepping Friskole. En friskole giver mulighed for at fokusere på den intenderede læreplan, da skolen ikke er underlagt den evaluerede læreplan. Forsøgsundervisningen omhandler cirka 220 lektioner i 5.-6. klasse, hvor jeg har observeret cirka 100 lektioner. Læreren og jeg etablerer et "rollebevidst partnerskab" (Blomhøj \& Jensen, 2007; Wagner, 1997), hvor læreren er en ligeværdig aktør, der har afgørende indflydelse på planlægning og tilrettelæggelse af undervisningen. Samarbejdet tager afsæt i en tænkning om, at læreren og forskeren skaber og agerer ud fra to forskellige typer af viden. Læreren anvender og udvikler sin egen praksisteori (Handal \& Lauvås, 2006), mens forskeren anvender og udvikler en videnskabelig viden. Selvom vi er fælles om at planlægge undervisningen, er det tydeligt, at vi tilhører to forskellige praksisfællesskaber med overlappende interesser, men asymmetriske behov (Goos, 2014). Indlejret i det rollebevidste partnerskab er en respekt for lærerens professionelle viden, hvor hun gennem samarbejdet kommer til at træffe valg på baggrund af didaktisk refleksive samtaler. Her udgør den hypotetiske læringskurs blandt andet et fælles repertoire i forbindelse med meningsforhandlingerne (Goos, 2014).

\section{Hindring af eksemplarisk karakter}

Lad os vende tilbage til den indledende fortælling fra femte klasse. Undervisningssekvensen viser en situation, hvor matematiklæreren indleder med at operationalisere intentionen om læringsmålstyring i en konkret klassekontekst. Sekvensen giver indblik i, at mål er et komplekst begreb for eleverne at forholde sig til, og eleverne viser divergerende forståelser for 
målbegrebet. I det efterfølgende vil jeg beskrive en række af de hindringer samt opmærksomhedsfelter, som er observeret i en konkret klasserumskontekst. Beskrivelserne vil blive relateret til to kompetencemål med tilhørende færdigheds- og vidensmål for matematik på mellemtrinnet (se figur 4).

\begin{tabular}{l|l|l} 
Matematisk kompetence & Problembehandling \\
\hline $\begin{array}{l}\text { Eleven kan handle med } \\
\text { overblik i sammensatte } \\
\text { situationer med matema- } \\
\text { tik }\end{array}$ & $\begin{array}{l}\text { Eleven kan anvende for- } \\
\text { skellige strategier til mate- } \\
\text { matisk problemløsning }\end{array}$ & $\begin{array}{l}\text { Eleven har viden om for- } \\
\text { skellige strategier til mate- } \\
\text { matisk problemløsning, } \\
\text { herunder med digitale } \\
\text { værktøjer }\end{array}$ \\
$\begin{array}{l}\text { Tal og algebra } \\
\begin{array}{l}\text { Eleven kan anvende } \\
\text { rationale tal og variable i } \\
\text { beskrivelser og beregnin- } \\
\text { ger }\end{array}\end{array}$ & $\begin{array}{l}\text { Eleven kan udføre bereg- } \\
\text { ninger med procent, } \\
\text { herunder med digitale } \\
\text { værktøjer }\end{array}$ & $\begin{array}{l}\text { Eleven har viden om stra- } \\
\text { tegier til beregninger med } \\
\text { procent }\end{array}$
\end{tabular}

Figur 4 Målbeskrivelser fra Forenklede Fælles Mål

\section{Målstyring som en ritualiseret handling}

Et centralt aspekt i forsøgsundervisningen er, at læreren introducerer eleverne for læringsmål i elevtermer. I løbet af det første halve år observeres gentagne gange en form for ritualiseret tilgang til målstyret undervisning. Betegnelsen "ritualiseret handling" er valgt fremfor "rutineret handling", da det relaterer sig til bevæggrunden for handlingen. Både rutine og ritual kan forstås som handlinger, der vanemæssigt gentages i samme form. Hvor rutiner ofte er dagligdagsaktiviteter uden refleksion, kan ritualer anskues som værende en kulturel, meningsfuld praksis, der relaterer sig til et bevidst formål. Læreren gør målstyret undervisning! Der er altså stor overensstemmelse mellem den intenderede læreplan og den gennemførte læreplan. Matematiklæreren introducerer eleverne for synlige læringsmål, dog uden at eleverne får mulighed for at forholde sig til dem. Her bliver de synlige målformuleringer et ritual i sig selv, der ikke relateres til elevernes læreproces. Endvidere observerer jeg nogle gange en overflod af målformuleringer (se figur 5, hvor nogle mål relaterer sig til målbeskrivelser i figur 4).

Et interessant element i den sammenhæng er, at læreren skaber et didaktisk begreb "mål-snak" som et udtryk for klasserumspraksissen med at italesætte mål over for eleverne. Som antydet giver mine observationer indblik 
Rune Hansen: På vej mod en målbevidst, målstyret kompetenceorienteret ...

i, at læreren på forskellige tidspunkter forfalder til en form for instrumentalisme i forbindelse med målarbejdet.

\section{Jamen jeg synes jo at...at det er blevet sådan lidt statisk, at man har det, at vi har det bare med, og så nævner man mål, og så tænker de egentlig ikke mere over det [...]altså jeg synes da, vi startede med at indføre det [...] fra sommerferien og herhen, der synes jeg, det gik super godt, og jeg synes, de begyndte virkelig og forholde sig til de her mål. Så er det ligesom om, vi træder vande nu (Lærerinterview).}

I udgangspunktet gør læreren egentlig bare, hvad vi gennem planlægningssamtaler har drøftet skal være centralt i undervisningen. Mine observationer og interviews får mig til at reflektere over målstyret matematikundervisning. De indledende analyser indikerer, at tilgangen ikke er konstruktiv i forhold til, hvad der bør karakterisere målstyret undervisning. Empirien fremkommer med en tydelig indikation af, at synlige læringsmål i klasserummet i sig selv ikke gør noget. Der er her identificeret en nærliggende risiko for, at ritualiseret målstyret undervisning afkobler en central dimension ved målstyret matematikundervisning, nemlig lærerens evne til at være didaktisk reflekteret. Faren for ritualiseret målstyring er en relevant pointe at gøre opmærksom på som en hindring for mange matematiklærere, der forsøger at praktisere en målstyret matematikundervisning. I et interview beskriver læreren, hvordan operationalisering af mål i undervisningen har udviklet sig:

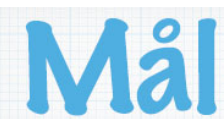

* Dukan fortælle, hvad procent betyder

* Du kan angive procent af en storrelse

* Dukan genkende og skrive tegnet for procent

Du kan omregne decimaltal og angive procent

* Dukan forklare, hvad hyppighed er

* Du kan forklare, hvad frekvens er

Figur 5 Skærmbillede fra lærerens præsentation
Men der var jeg mere bevidst om, at der var nogen af ordene, der var markeret i hvert mål, som vi så gik ind og talte om. Hvad betyder det her ord helt præcist? Sådan så målet egentlig blev mere, at de vidste, hvad det 
Rune Hansen: På vej mod en målbevidst, målstyret kompetenceorienteret ...

indebar. Og der synes jeg, at der er jeg måske gået over til, at det bliver lidt for overfladisk, at det bliver bare vist, det bliver læst op, og vi får måske lige snakket om det, og så i opsamlingen følger vi lidt op på det, men æh...jeg tænker, at det måske mangler noget der også (Lærerinterview).

\section{Didaktisk målbevidst målstyring}

Det langvarige undersøgelsesdesign muliggør cykliske processer, hvor der er tid og plads til at nå frem til delerkendelser, der kan forfølges i feltarbejdet. Med baggrund i observationerne fastholdes idéen om, at der skal være tydelighed om læringsmål i undervisning. Vi revurderer dog, hvad det egentlig vil sige at være tydelig i klasserummet. De cykliske processer gør det muligt at tage lærerens didaktiske tænkning om målstyring op og forsøge at afritualisere den gennem forskellige tiltag. I didaktiske refleksive samtaler med læreren vender vi tilbage til, hvad ambitionen med synlige læringsmål i klassen egentlig er. I den skitserede form med den ritualiserede "mål-snak" er der ingen tvivl om, at lærerens egen orkestrering af undervisningen er målstyret.

\section{Men jeg synes, at det der overblik vi har over... når vi får lavet de der forløb og får lavet målene og lavet aktiviteterne og får skrevet [...]hvad der kan være tegn på læring, og hvad er det undersø- gende og sådan noget. Jeg synes, man har et rigtig godt funda- ment, når man starter (Lærerinterview).}

Udfordringen er dog at få eleverne til at arbejde aktivt med at forstå og forholde sig til læringsmålene. Vi bliver enige om at eksperimentere med forskellige tilgange til ambitionen om at bruge læringsmål. Her overvejes, hvornår det er centralt, at eleverne møder et læringsmål, og under hvilke omstændigheder det giver mening, at eleverne ikke ser en målformulering. I udviklingen af en didaktisk målbevidst målstyring hos læreren bliver et centralt omdrejningspunkt didaktiske refleksioner over, hvornår eleverne skal møde synlige læringsmål. I forbindelse med afritualiseringen bliver det tydeligt, at de synlige læringsmål har været med til at orientere lærerens tænkning om undervisningens indhold i en travl hverdag, hvor hun uden pause går fra en undervisningskontekst til en anden:

Jeg oplevede egentlig, da jeg sad derhjemme og planlagde lidt, at jeg selv glemte dem en lille bitte smule. Og så tænkte jeg, Nej dem 
Rune Hansen: På vej mod en målbevidst, målstyret kompetenceorienteret ...

\section{skal jeg lige have skrevet op i min Keynote. Og så skrev jeg dem egentlig op, så jeg hver gang - dem viste jeg så ikke til børnene - lige havde dem for øje, når jeg planlagde. Så jeg ikke hurtigt kom tilbage til det gamle (Lærerinterview).}

De matematiske kompetencers forskellige karakteristika giver os en idé til at eksperimentere med elevernes tænkning om deres læring. Her vurderes, at eksempelvis symbolbehandlingskompetence og hjælpemiddelkompetence meningsfuldt kan iscenesættes med designede opgaver, hvor eleverne gennem opgaverne kan identificere læringsintentionerne. Med afsæt i ovenstående målformuleringer om digitale værktøjer behøver eleverne ikke at møde et instruktivt læringsmål som, "Du kan opstille en hyppighedstabel i Numbers", hvis opgaverne netop omhandler at opstille en sådan tabel i et regneark. Her retter opgaverne i sig selv elevernes opmærksomhed mod læringsintentionen. Noget tilsvarende er ofte ikke tilfældet ved modellerings- og problembehandlingskompetencen, der fordrer en mere tydelig formidling af intentionerne med at udvikle disse kompetencer. I forbindelse med problembehandlingskompetencen udvikles mere instruktive målformuleringer som, "du kan gennemføre en systematisk undersøgelse, når du løser et problem", til mere ekspressive målformuleringer som, "du kan beskrive, hvad der kendetegner en god problemløser". Begrebet "god problemløser" etableres i det uddannelsesmæssige møde mellem lærer og elever og er med til at rette elevernes læringsintention mod centrale karakteristika ved kompetencen. Modsat beskrivelserne fra Skott og Kaas (2015) bliver målformuleringen en væsentlig del af lærerens planlægning, hvor den er med til at skabe en undervisningsmæssig retning (Carlsen et al., 2016).

\section{Udvikling af elevers forståelser af mål}

Et centralt element i forsøgsundervisningen er, at eleverne kan forholde sig til synlige målformuleringer. Men som den indledende undervisningssekvens giver indblik $i$, har eleverne divergerende opfattelser af, hvad der kendetegner mål. I selve situationen beskriver nogle elever også, at mål relaterer sig til, "noget man gerne vil opnå" og at "lære det som man har sat sig for". I løbet af forsøgsundervisningen sker der dog et skifte, hvor eleverne begynder at relatere deres forståelser for mål til undervisnings- og læringssituationer. Eleverne har dog stadigvæk forskellige målforståelser. Nogle elever relaterer mål til aktiviteterne i matematikundervisningen. At lave opgaver bliver et mål i sig selv for en del elever, eller som en elev beskriver i en plenumsamtale: 
Rune Hansen: På vej mod en målbevidst, målstyret kompetenceorienteret ...

Opgaverne, der er et mål, at vi skal nå alle dem, vi har fået for, eller dem vi skal lave. Det er et mål og nå alle dem.

I samme plenumsamtale fremkommer andre elever med følgende formuleringer:
Vi får et mål i starten af timen. Så skal vi lære det gennem mate- matik, hvad hedder det nu, undervisningen. Så har vi swift [lyd] nået det.
For eksempel nu er vi begyndt på det her, og så måske hvis vi har det i fire uger eller sådan noget, så når de fire uger er gået, så skal vi gerne have opnået det mål. Så altså vi startede med at sætte mål om at lære det der, og så når vi er færdige, så skal vi gerne have opnået det.

Der er altså identificeret en målforståelse hos nogle elever, der hviler på en form for aktivitetsmål. For nogle elever er målet at nå at lave aktiviteten, mens andre relaterer mål til, hvad de skal lære. Aktivitetsmål relaterer sig til en form for præstationsorientering, hvor eleverne opnår succes ved at lave opgaverne uden at reflektere over, hvad de lærer. Det kan pege tilbage på den opgaveorienterede kultur, som matematikundervisningen er præget af. Det er en hæmmende faktor i en målstyret undervisning, at nogle elever har problemer med at forholde sig til deres egen læring.

Der indgår en række proceselementer ved at formulere og anvende læringsmål i undervisningen. Først skal læreren overveje, hvad der er centralt, og hvordan det formuleres i elevtermer. Herefter skal eleverne kunne afkode den intentionalitet, der er indlejret i læringsmålene. Der er altså flere steder, hvor der kan opstå problematiske situationer, når eleverne via målene skal reflektere over deres læring. I forbindelse med en observation fra det første forløb fortæller Tine eleverne, at de skal lave en smiley indikerende "kan, kan næsten, kan ikke" på en liste med forskellige læringsmål.

Ved et bord sidder to piger, Lise og Pia. De er meget usikre på, hvad de skal gøre. På et tidspunkt læser Pia op: "Tegne en trekant ved brug af vinkelmåler, når du kender tre forskellige oplysninger. Hvad mener hun med det?"

Lise svarer: "Jeg ved det ikke. Jeg sætter bare en smiley, så laver jeg, når jeg ikke fatter det, så laver jeg sådan en streg." 
Rune Hansen: På vej mod en målbevidst, målstyret kompetenceorienteret ...

\section{Lise viser det for Pia ved at tegne en smiley på bordet og udbry- der: "Jeg fatter det ikke" (Klasserumsobservation).}

Mine observationer indikerer, at når elever har svært ved at forstå en målformulering, begynder de at anvende forskellige afværgestrategier eksempelvis ved at markere, at de har opnået målet, selvom de ikke kan forstå formuleringen.

\section{Ja, jeg ved ikke helt. Nogen...jeg har sat JA ved nogen, og jeg ved ikke helt, om jeg har det sådan, det er kun sådan lidt, jeg skal bare have det forklaret først, tror jeg (Elevgruppeinterview).}

Mine data giver indblik $i$, at der er centrale matematiske elementer, som det er problematisk at beskrive i læringsmål i elevtermer. Noget lignende konkluderer Skott og Kaas (2015). I forbindelse med planlægning af undervisningen skal læreren altså både overveje, om der er tale om et centralt indholdselement, samt om det kan beskrives på en meningsfuld måde som et læringsmål. I den forbindelse er der tydelige indikationer på, at en del elever har vanskeligheder ved at afkode de læringsmål, der relaterer sig til de matematiske kompetencer. Med afsæt i eksemplet fra før viser flere observationer, at eleverne har svært ved at forklare, hvad der kendetegner en systematisk undersøgelse. Det fører som ovenfor beskrevet til målformuleringen om "den gode problemløser", hvor eleverne i flere observationer giver udtryk for, at "de skal huske og være gode problemløsere". Det er et centralt opmærksomhedsfelt for enhver matematiklærer at få dannet ekspressive målformuleringer i det uddannelsesmæssige møde, da det ellers kan føre til en ubevidst fokusering på instruktive målformuleringer relateret til de matematiske stofområder. De instruktive målformuleringer er også mere enkle at observere for matematiklæreren i forbindelse med observationer af elevernes læringsudbytte (den lærte læreplan). Eksempelvis er det lettere at observere, om eleverne kan lave en hyppighedstabel i et regneark, end om de er blevet gode problemløsere. En alvorlig hæmmende faktor for den kompetenceorienterede matematikundervisning vil være, at de synlige målformuleringer implicit fører til en mere færdighedsorienteret tilgang, hvor der udelukkende fokuseres på de matematiske stofområder.

Intentionen med den indledende undervisningssekvens er at tydeliggøre, at elever har meget forskellige opfattelser af mål i undervisningen. Hvor nogle elever giver udtryk for, at "det ryger ind af det ene ore og ud af det andet" 
Rune Hansen: På vej mod en målbevidst, målstyret kompetenceorienteret ...

(Elevgruppeinterview), forklarer andre elever, at det får dem til at reflektere over deres egen læreproces. Som to elever beskriver det i et gruppeinterview:

\section{$\mathrm{E}_{1}$ : Jeg kan godt tænke nogle gange, jeg har ikke opnået målet i dag. Eller jeg kan også godt tænke, jeg har i hvert fald opnået målet i dag. \\ I: Hvordan kan man vide, at man har opnået målet? Det er rigtig interessant, synes jeg. \\ $\mathrm{E}_{1}$ : Det kan man vide, fordi det er, man føler, man har lavet meget, og man har arbejdet godt. \\ $\mathrm{E}_{2}:$ Og man føler, at man ved, hvad det er... \\ $\mathrm{E}_{1}$ : ... man snakker om (Elevgruppeinterview).}

\section{Diskussion}

Gennem mit projekt forsøger jeg at stille skarpt på aspekter, der fremmer og udfordrer en målstyret kompetenceorienteret matematikundervisning. Ved at anvende begreberne den intenderede, den gennemførte, den evaluerede og den lærte læreplan som perspektiver på målstyret undervisning etableres en række opmærksomhedsfelter. Hvor Skott og Kaas (2015) beskriver, at lærerene ikke har et behov for eksempelvis at konkretisere målene fra den intenderede læreplan, giver læreren i mit projekt udtryk for, at målene er med til at orientere hendes tænkning om undervisningen. Der er tydelige indikationer på, at det er en meningsfuld didaktisk aktivitet for læreren at fokusere på mål i forbindelse med et specifikt matematisk indholdsområde (den gennemførte læreplan). Som beskrevet tilkendegiver læreren, at hun "synes, man har et rigtig godt fundament, når man starter." Hodgson et al. (2012) konkluderer, at måldrevet læring kan være en tilnærmelse til undervisning, men påpeger samtidig risikoen for en negativ fragmentering af læringsarbejdet. Carlsen et al. (2016) beskriver, at målstyring for den fagligt usikre lærer kan være et nyttigt stillads. I forhold til matematikfaget viser mine analyser $\mathrm{dog}$, at det fordrer et stort fagligt overskud at operationalisere koblingen mellem fagligt stof og matematisk kompetence. Derved kan den usikre lærer komme til at stå i en situation, hvor styringen relaterer sig til instruktive målbeskrivelser i forhold til fragmenterede dele af stofområderne, hvor eleverne ikke får mulighed for at udvikle matematisk kompetence til at handle hensigtsmæssigt i situationer, som rummer en matematisk udfordring. 
Mine resultater viser, at der er en nærliggende risiko for, at matematiklæreren gør målstyret undervisning med afsæt i instruktive færdighedsorienterede mål (se fx figur 5). Derved kan matematikundervisningen blive reduceret til små forløb med nøje beskrevne færdighedsmål, der har en stærk relation til den evaluerede læreplan og udvikling af en præstationsorienteret kultur i klasserummet. Med begrebet ritualiseret målstyring henvises til en form for målstyring, hvor matematiklæreren dels i udgangspunktet indfrier forventningerne fra Undervisningsministeriet om at bedrive målstyret undervisning, dels afmonterer sin egen didaktiske refleksion over målenes betydning for undervisningen og elevernes læring. Undersøgelsens langstrakte design skaber en situation, hvor matematiklæreren løbende afkræves refleksion over betydningen af forskellige typer af mål i undervisningen. Undersøgelsen kunne reelt være afsluttet efter tre måneder, hvor dataene gav tydelige indikationer på en ritualiseret form for målstyring. Dog tillader den didaktiske modelleringsproces, at der arbejdes med iterative processer, hvorfor den ritualiserede tilgang blev udfordret i forsøget på at udvikle en bevidsthed om måls betydning for at skabe en rettethed i undervisningen. Synlige læringsmål kan være med til at understøtte det. Dog vil det være forkert at slutte, at synlige læringsmål automatisk bibringer undervisningen en rettethed. Mine empiriske resultater giver indblik $i$, at det ikke er en naturlig følgeslutning.

De matematiske kompetencer rummer en ambitiøs forandring af matematikundervisning. Mit forskningsprojekt giver indblik i, at det tager tid for matematiklæreren at opnå en fortrolighed med kompetencerne, så hun kan operere med dem på reflekteret vis i sin praksis. Hensigten med artiklen har blandet andet været at beskrive én lærers arbejde med forståelse af og indførelse af målstyret kompetenceorienteret matematikundervisning. De beskrevne resultater i artiklen åbner for en begrundet interesse for, om matematiklærerens til tider usikre anvendelse af læringsmål er et mere generelt fænomen. Det bevidste metodiske valg med at fokusere på hindringer skaber opmærksomhedsfelter for matematiklærere, lærerstuderende og læreruddannere, der forhåbentlig kan stimulere til refleksion over den tænkning og de styringsmekanismer, der aktuelt dominerer såvel læreruddannelsen som lærerprofessionen i forbindelse med udvikling af målstyret kompetenceorienteret matematikundervisning.

\section{Referencer}


Rune Hansen: På vej mod en målbevidst, målstyret kompetenceorienteret ...

Aftale om et fagligt løft af folkeskolen. (2013). Hentet fra: http://www.kl.dk/ImageVault/ Images/id_62271/scope_0/ImageVaultHandler.aspx

Bergqvist, E., Bergqvist, T., Boesen, J., Helenius, O., Lithner, J., Palm, T., \& Palmberg, B. (2010). Matematikutbildningens mål och undervisningens ändamålsenlighet. Grundskolan våren 2009.

Blomhøj, M., \& Højgaard, T. (2011). Hvad er meningen? Didaktisk klasseledelse i matematik via form eller indhold. I:Schmidt, M.-C.S. (Ed.), Klasseledelse og fag - at skabe klassekultur gennem fagdidaktiske valg (s. 143-163). Dafolo.

Blomhøj, M., \& Jensen, T.H. (2007). SOS-projektet - didaktisk modellering af et sammenhængsproblem. MONA(3), 25-53.

Boesen, J., Helenius, O., Bergqvist, E., Bergqvist, T., Lithner, J., Palm, T., \& Palmbergb, B. (2014). Developing mathematical competence: From the intended to the enacted curriculum. Journal of Mathematical Behavior(33), 72-87.

Borgnakke, K. (2013). Etnografiske metoder i uddannelsesforsknngen - mellem klassiske traditioner og senmoderne udfordringer: Institut for Medier, Erkendelse og Formidling, Det Humanistiske Fakultet, Københavns Universitet.

Brinkmann, S., \& Kvale, S. (2008). InterView Introduktion til et håndværk. København: Hans Reitzels Forlag.

Carlsen, D., Tamborg, A., \& Hansen, R. (2016). Læreres målforståelser. Læremiddel.dk. Hentet fra: http://auuc.demonstrationsskoler.dk/forskningsprojekter/1\%C3\%A6reres-m\%C3\%A5lforst $\% \mathrm{C} 3 \%$ A5elser/rapporter-og-bilag/1\%C3\%A6reres-m\%C3\%A5lforst $\%$ C3\%A5elser

Danmarks Evalueringsinstitut. (2006). Matematik på grundskolens mellemtrin - Skolernes arbejde med at udvikle elevernes matematikkompetencer.

Danmarks Evalueringsinstitut. (2012). Fælles Mål. En undersøgelse af lærernes brug af Fælles Mål.

Eisner, E.W. (1967). Educational objectives: help or hindrance? School Rev., 75(3), 250-260.

Eisner, E.W. (1969). Instructional and Expressive Educational Objectives: Their Formulation and Use in Curriculum. I Popham, W.J., Eisner, E.W., Sullivan, H. \& Bruneau, W. (Eds.), Instructional Objectives (s. 1-18). Chicago, IL: McNally \& Co.

Empson, S.B. (2011). On the idea of learning trajectories: Promises and pitfalls. The Mathematics Enthusiast, 8(3), 571-596.

Flyvbjerg, B. (2010). Fem misforståelser om casestudiet. I: Brinkmann, S. \& Tanggaard, L. (Eds.), Kvalitative metoder: en grundbog (s. 463-487). København: Hans Reitzels Forlag.

Goos, M. (2014). Researcher-teacher relationships and models for teaching development in mathematics education. ZDM, 46(2), 189-200.

Handal, G., \& Lauvås, P. (2006). Vejledning og praksisteori. Århus: Forlaget Klim.

Hansen, R. (2015). At styre efter målet i matematik: hvad ved vi egentlig om elevers og læreres målorientering? MONA(1), 7-23.

Hodgson, J., Rønning, W., Skogvold, A. S., \& Tomlinson, P. (2010). På vei fra læreplan til klasserom Nordlandsforskning, NF-rapport.

Hodgson, J., Rønning, W., \& Tomlinson, P. (2012). Sammenhengen mellom undervisning og læring. En studie av læreres praksis og deres tenkning under Kunnskapsløftet. Sluttrapport Nordlandsforskning, NF-rapport (Vol. 4).

Højgaard, T. (2013). Kompetencemål, faghæfte og fokuseret matematikundervisning. I: Andersen, M.W. \& Weng, P. (Eds.), Håndbog om matematik i grundskolen (s. 34-47): Dansk Psykologisk Forlag.

Højgaard, T., \& Hansen, R. (2016). Didactical Modelling. Paper presented at the ICME 13 International Congress on Mathematical Education, Hamburg.

Lindhardt, B. (2016). Hvilke kompetencer? Hentet fra http://www.folkeskolen.dk/581910/ hvilke-kompetencer 
Rune Hansen: På vej mod en målbevidst, målstyret kompetenceorienteret ...

Mager, R.F. (1962). Målsætning i undervisningen. Gyldendal.

Mager, R.F. (1968). Bevar elevens interesse for Deres fag. Gyldendal.

Master for forenkling af Fælles Mål. (2013). Hentet fra: http://www.uvm.dk/Uddannelser-og-dagtilbud/Folkeskolen/Faelles-Maal/Praecisering-og-forenkling-af-Faelles-Maal/ /media/UVM/Filer/Udd/Folke/PDF13/Faelles\%20Maal/130923\%20Master\%20 til\%20praecisering\%20og\%20forenkling\%20af\%20Faelles\%20Maal.ashx

Meece, J.L., Anderman, E.M., \& Anderman, L.M. (2006). Classroom Goal Structure, Student Motivation, and Academic Achievement. Annual Review of Psychology(57), 487-503.

Midgley, C., Kaplan, A., \& Middleton, M. (2001). Performance-approach goals: Good for What, for Whom, under What Circumstances, and at What Cost? Journal of Educational Psychology, 93(1), 77.

Misfeldt, M. (2016). Digitalt Understøttede Læringsmål: Udviklingsprojekt med demonstrationsskoleforsøg vedr. it i folkeskolen (Slutrapport): Aalborg Universitet.

Mogensen, A. (2011). Point-driven mathematics teaching: studying and intervening in Danish classrooms. PhD dissertation. Roskilde: Roskilde University, IMFUFA.

Newman, R.S., \& Schwager, M.T. (1995). Students' help seeking during problem solving: Effects of grade, goal, and prior achievement. American Educational Research Journal, 32(2), 352-376.

Niss, M. (2001). Kompetencebegrebet i beskrivelsen af matematik som undervisningsfag. Matematik(3).

Niss, M. (2015). Hovedlinjer i den historiske udvikling af matematikkens didaktik. Præsenteret ved Matematikvejlederkonference, Odense.

Niss, M. (2016). Målstyret matematikundervisning?! MONA(1), 69-73.

Niss, M., \& Jensen, T.H. (2002). Kompetencer og matematiklæring. Ideer og inspiration til udvikling af matematikundervisning i Danmark: Undervisningsministeriet.

Porter, A.C., \& Smithson, J.L. (2001). Defining, developing, and using curriculum indicators. Consortium for Policy Research in Education. University of Pennsylvania. Graduate School of Education. Hentet fra: http://repository.upenn.edu/cgi/viewcontent.cgi?article $=1058 \&$ context $=$ cpre_researchreports

Progression i de naturvidenskabelige fag. (2014). Hentet fra: http://www.emu.dk/sites/ default/files/Rapport\%20Progression\%20i\%20naturvidenskab\%20Marts\%202014.pdf

Remillard, J.T. (2005). Examining key concepts in research on teachers' use of mathematics curricula. Review of Educational Research, 75(2), 211-246.

Roald, T., \& Køppe, S. (2008). Generalisering i kvalitative metoder. Psyke \& Logos, 29(1), 14.

Simon, M.A. (1995). Reconstructing mathematics pedagogy from a constructivist perspective. Journal for research in mathematics education, 114-145.

Simon, M.A. (2006). Key developmental understandings in mathematics: A direction for investigating and establishing learning goals. Mathematical thinking and learning, 8(4), 359-371.

Simon, M.A., \& Tzur, R. (2004). Explicating the role of mathematical tasks in conceptual learning: An elaboration of the hypothetical learning trajectory. Mathematical thinking and learning, 6(2), 91-104.

Skott, C.K., \& Kaas, T. (2015). Matematiklæreres planlægningspraksis og læringsmålstyret undervisning. MONA(4).

Sullivan, P., Tobias, S., \& McDonough, A. (2006). Perhaps the Decision of Some Students Not to Engage in Learning Mathematics in School Is Deliberate. Educational Studies in Mathematics, 62(1), 81-99.

Turner, J.C., Thorpe, P.K., \& Meyer, D.K. (1998). Students' Reports of Motivation and Negative Affect: A Theoretical and Empirical Analysis. Journal of Educational Psychology, 90(4), 758-771. 
Rune Hansen: På vej mod en målbevidst, målstyret kompetenceorienteret ...

Tyler, R. (1977). Undervisningsplanlægning. København: Christian Ejlers' Forlag.

Undervisningsministeriet. (2009). Fælles Mål 2009 Matematik. København: Undervisningsministeriet.

Undervisningsministeriet. (2010). Introduktion til den danske kvalifikationsramme for livslang læring: Undervisningsministeriet i samarbejde med Ministeriet for Videnskab, Teknologi og Udvikling, Økonomi- og Erhvervsministeriet og Kulturministeriet.

Undervisningsministeriet. (2014). Læringsmålstyret undervisning i folkeskolen. Vejledning.

Wagner, J. (1997). The Unavoidable Intervention of Educational Research: A Framework for Reconsidering Researcher-Practitioner Cooperation. Educational Researcher, 26(7), 13-22.

Wolters, C.A. (2004). Advancing Achievement Goal Theory: Using Goal Structures and Goal Orientations to Predict Students' Motivation, Cognition, and Achievement. Journal of Educational Psychology, 96(2), 236-250. 